\title{
As raízes renegadas da teoria do capital humano
}

RENATO P. SAUL*

We hold these truths to be self-evident, that all men are created equal, that they are endowed by their Creator with certain unalienable Rights, that among these are Life, Liberty and the pursuit of Happiness. - That to secure these rights, Governments are instituted among Men, deriving their just powers from the consent of the governed, - That whenever any Form of Government becomes destructive of these ends, it is the Right of the People to alter or to abolish it, and to institute new Government, laying its foundation on such principles and organizing its powers in such form, as to them shall seem most likely to effect their Safety and Happiness.

The unanimous Declaration of the thirteen united States of America.In Congress, july 4, 1776 .

"Se a universidade não é uma mera fábrica de graus acadêmicos ou uma escola pré-vocacional que representa os estreitos interesses de uma classe econômica especializada, mas esse serviço intelectual e científico público que queremos que seja, seu governo deve diferir de uma companhia de mineração e a situação dos professores diferir da de um empregado de ferrovia. Os professores devem contar com alguma segurança em seu posto".

Randolph Bourne, jornalista e militante anarquista, ([1915] (1965, p. 75).

"If any workman were to find a new and quicker way of doing work, or if he were to develop a new method, you can see at once it becomes to his interest to keep that development to himself not to teach the other workman the quicker method. It is to his interest to do what workmen have done in all times, to keep their trade secrets for themselves and their friends. That is old idea of trade secrets. The workman kept his knowledge to imself instead of developing a science and teaching it to others and making it public property". Frederick Taylor. Taylor's Testimony before the Special House Cometee. 1912.

\footnotetext{
*Sociólogo, professor titular jubilado da UFRGS. Endereço eletrônico: rpsaul@uol.com.br
} 


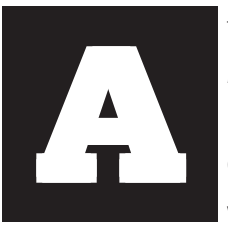

teoria do capital humano é resultado, na perspectiva de Mark Blaug (1985, cap.13), de um programa de pesquisa, uma vez que não é possível associá-la a uma única teoria. O núcleo desse programa "consiste na idéia de que o indivíduo gasta em si mesma de formas diversas, não apenas buscando desfrutar o presente, mas procurando rendimentos futuros, pecuniários ou não". De acordo com Blaug, a teoria foi anunciada por Theodore Schultz, em 1960, e seu "nascimento efetivo" teria ocorrido em 1962 em suplemento da revista científica americana Journal of Political Economy, dedicado ao tema do investimento em seres humanos. Em outro texto (1986, p. 691-2), Blaug localiza as fontes primárias da teoria em Adam Smith, em Alfred Marshall e nos estudos de Irving Fisher, economista neoclássico americano, que a teria exposto em 1906, no livro The Nature of Capital and Income. Reprints of Economic Classics. Fisher teria adotado a teoria do capital de Walras, entendendo por capital todo o conjunto de riquezas existentes em um determinado tempo e que possibilitam o fluxo de serviços nesse tempo, trate-se da terra, das máquinas, das matérias primas, de recursos naturais e das qualidades do homem. O fluxo de serviços durante um período de tempo consistiria na renda.

Lars Nerdrum e Truls Erikson (2001) acrescentam à relação de fontes da teoria o nome de William Petty, como o primeiro economista a enfatizar as diferenças de qualidade do trabalho e a identificar o que, mais tarde, viria a ser conhecido como capital humano, quando defendeu a inclusão do valor do trabalhador nos registros atuariais. Nerdrum e Erikson sustentam que a noção de capital de Fisher é a fonte primária da teoria moderna do capital humano, na forma em que ela surgiu, no fim da década de 1950. Trabalhando separadamente e a partir de perspectivas diferentes Jacob Mincer e Theodore Schultz seriam os autores que, partindo de Fisher, entenderiam o capital humano como um capital independente do capital convencional em relação às características econômicas e produtivas de um país. 
A partir de alguns textos desses dois últimos autores, podemos perseguir a linha central da lógica de desenvolvimento do conceito, na sua origem, a economia americana.

Jacob Mincer (1958) examinou a questão do capital humano numa perspectiva econométrica, buscando a correlação entre o investimento na formação do trabalhador e a distribuição de renda pessoal. A sua análise indicou que a decisão de despender tempo para melhorar o desempenho no trabalho era resultante de uma escolha individual e racional, que as diferenças entre as ocupações eram função de diferenças no treinamento e que essas diferenças surgiam quando o conceito de investimento e capital humano era estendido para incluir a experiência no emprego. Buscando a relação entre investimento em capital humano e a produtividade, Mincer extraía uma conclusão provisória no sentido de que a dispersão dos rendimentos entre as diferentes ocupações deveria estar relacionada positivamente ao volume do investimento em capital humano feito nelas.

Em discurso proferido no encontro da associação americana de economia, em dezembro de 1960, Theodore Schultz (1961), especialista em economia agrícola e então presidente da referida associação, buscou estabelecer a substância do capital humano e as condições da sua formação, sustentando residir nessa forma de entender a capacitação das pessoas a resolução de muitos paradoxos e confusões a respeito da dinâmica de crescimento econômico dos Estados Unidos. Na sua avaliação, o investimento em capital humano devia ser considerado como diferente de consumo, tanto pelas suas dimensões quantitativas quanto pelas dimensões qualitativas. Não obstante a dificuldade de medição desse tipo diferenciado de capital, algumas atividades poderiam ser destacadas como promovendo as capacidades humanas. Assim, por exemplo, os serviços de saúde, entendidos em sentido amplo, envolvendo as despesas que afetem a expectativa de vida, o vigor e a vitalidade das pessoas. Outro ponto a considerar era o treinamento no emprego, incluindo o velho estilo de aprendizagem organi- 
zado pelas empresas. Também deveria incluir-se a educação formal, em seus diferentes níveis. Também incluíam-se aí os programas de educação de adultos, não organizados por empresas, incluindo os programas de extensão, principalmente na agricultura. Por último, mas não menos importante, Schultz citava o processo de migração de indivíduos e de famílias para ajustar-se às oportunidades de emprego, em constante transformação.

Para Schultz, o equívoco em desconsiderar os recursos humanos como uma forma de capital, ou seja, de vê-lo como um meio de produção, como um produto de investimento, fomentou a sustentação de uma clássica e superada noção de trabalho, na economia em geral. Essa noção correspondia a entender o trabalho como a capacidade de realizar trabalho manual que exigisse escasso conhecimento e especialização. De acordo com essa forma de ver o trabalho, os trabalhadores eram pensados como uniformemente dotados. Entender o trabalho como medida de um fator econômico dessa natureza seria não menos sugestivo do que contar as máquinas para determinar a sua importância como capital ou como fluxo de serviços produtivos. "Essa noção de trabalho estava equivocada no período clássico e está evidentemente errada agora" (Ibid., 1961, p. 3).

Os estudos sobre capital humano difundiram-se com extraordinária velocidade nos Estados Unidos, principalmente, mas também em outros países. Em 1962, era divulgado um conjunto de estudos sobre o tema e, em 1963, surgia o primeiro livro texto de autoria de Theodore Schultz: The economic value of education. Comentando a reação positiva ao tratamento econômico da questão educacional, Mark Blaug, em 1968, na introdução de um volume institulado Economics of Education, identificou, no fenômeno, uma espécie de revolução silenciosa processando-se rapidamente nos objetivos dos estudos sobre o crescimento econômico: "a economia da educação com seu conceito de capital humano transformou rapidamente grandes áreas da economia ortodoxa, para emergir em 1960 como uma disciplina madura por seu próprio direito" (1971, p. 7). Em 1964, a discussão 
ampliava-se com uma outra obra que passaria a ser referência obrigatória no campo dos estudos sobre investimentos na formação dos trabalhadores, na saúde, na migração, etc. Tratava-se de Human Capital, de Gary Becker. Becker e outros desenvolveriam a seguir estudos sobre a economia da família, utilizando como base do programa de investigação a teoria do capital humano.

Em 1980, Mark Blaug (1985, p. 264-6) fez uma avaliação da trajetória da teoria do capital humano. Uma vez que um programa marxista de investigação sobre o assunto não chegava, no seu entendimento, a alcançar a teoria do capital humano em seu próprio terreno, a solução era realizar o julgamento da teoria em seus próprios termos. Neste sentido, Blaug entendia que a teoria se encontrava em situação crítica, em virtude de não oferecer uma explicação convincente sobre a demanda privada de educação, por não examinar esquemas de financiamento da educação, não considerando a propriedade pública de escolas e universidades, por não levar em conta o papel da aprendizagem gratuita através da prática, desprezando os estímulos dos mercados internos de trabalho, por não oferecer cálculos aceitáveis a respeito das taxas de rendimento entre os diferentes tipos de investimentos na formação de capital humano e também em razão de que a retomada de cálculos para rever resultados contraditórios das análises terminavam por fazer degenerar o programa de investigação.

Mas nem tudo era negativo no balanço feito por Blaug. De uma parte, o programa se havia afastado de algumas posições marcadas pela "ingenuidade" e avançara resolutamente na abordagem de temas não tratados pela economia, como a questão da renda pessoal. Por outra parte, o programa havia revelado a conexão entre fenômenos tradicionalmente abordados separadamente, como, por exemplo, a correlação descoberta entre a educação e os rendimentos em idades concretas, mostrando que seriam resultantes de decisões individuais. E, nesse ponto, Blaug (ibid., p. 254) ressalta a dominância do individualismo metodológico nos principais investigadores 
do programa. Ou seja, a idéia de que os fenômenos sociais podem e devem ser pensados como tendo seus fundamentos no comportamento individual, e que a formação do capital humano deve ser concebida em termos de decisões de indivíduos que atuam em defesa de seus interesses próprios. Nas escolhas individuais reside mesmo a quinta-essência da investigação sobre capital humano.

Um fato era destacado por Blaug para indicar uma circunstância importante da relação entre economia e investimento na formação do trabaIho, no contexto da sociedade americana, demonstrando que o conceito de capital humano, tal como era desenvolvido por Mincer, Schultz e Becker, estava fundado na perspectiva do cálculo privado. O fato em questão era relativo à "total ausência" de soluções governamentais quanto à formação profissional, pelo menos até 1968. Qual o sentido real dessa observação de Blaug, além de seu propósito de justificação do uso do individualismo metodológico na base da teoria do capital humano?

A relação entre a esfera privada e a formação profissional, a realização da pesquisa científica e do desenvolvimento de novas tecnologias, na sociedade americana, é bastante estreita e de longínqua data, muito embora nem sempre mereça a atenção devida. Nesse sentido, pode-se tomar em consideração os estudos de Loren Baritz (1961) cujo núcleo de preocupações foi o de tentar estabelecer o papel dos intelectuais nas atividades produtivas, em especial da integração de diferentes categorias de cientistas sociais à vida industrial americana, principalmente a partir dos anos 20 a 30, do século passado.

As observações de Baritz fornecem uma pista bastante sólida não apenas para desvendar o processo através do qual, na sociedade americana, operou-se a articulação entre as empresas e as universidades, mas também para entender a evolução de algumas situações nas relações de trabalho que sugerem uma forma de balizamento da elaboração da teoria do capital humano. Tomando em conta as considerações de Baritz no capítulo primeiro de 
seu livro observa-se que os empresários americanos, devido ao paternalismo dominante nas relações industriais, tardaram um pouco a perceber qual era o seu papel nas transformações que se operavam na economia, em fins do século 19. O aumento progressivo das empresas, o processo de burocratização, de especialização e de dispersão do controle que experimentavam então deixavam os empresários desorientados e inseguros, tardando em se darem conta do fato de que o conhecimento das relações sociais era tão importante quanto a habilidade técnica. A compreensão de que o conhecimento do homem e as relações humanas eram decisivas também no plano econômico só gradualmente se difundiu entre os grupos empresariais.

Além do desenvolvimento interno das empresas, um fato que contribuiu para aumentar a confusão do empresariado e apressar a busca de soluções fora da fábrica para seus problemas internos foi a organização sindical e a mudança na ideologia dos trabalhadores, que passavam a pressionar no sentido do reconhecimento do valor dos trabalhadores como homens. A esse fato se somou o grande contingente de trabalhadores americanos que foram incorporados ao exército, por ocasião da Primeira Guerra. A redução do mercado de trabalho reforçou ainda mais a ação dos sindicatos. A busca de postos de trabalho no meio industrial, por parte de grandes grupos de uma segunda geração de imigrantes mais bem adaptados à vida americana, também funcionou no sentido da exigência da adoção de novos tipos de tratamento nas relações de trabalho. Foi por essa época, aponta Baritz, que os empresários começaram a acreditar em que o comportamento humano poderia repercutir na atividade produtiva e pensaram em "incluir a máquina humana em seus cálculos" (op. cit., p. 34-5). A busca de especialistas em questões de comportamento nas universidades projetou-se como a possibilidade de criar uma nova situação para o controle das empresas.

A participação de especialistas não ligados diretamente ao campo econômico e à atividade industrial iria reforçar as expectativas e a confiança dos empresários na utilização de profissionais das ciências sociais como coadju- 
vantes da organização das relações sociais dentro dos seus estabelecimentos. Os sociólogos, antropólogos, psicólogos e outros especialistas, como pesquisadores integrados na busca da solução do problemas das relações humanas, passavam a assumir, assim, função decisiva na reorganização das relações de poder no interior das empresas e assegurar a imagem de humanização das relações de trabalho perante a sociedade.

O primeiro passo significativo nessa direção foi o uso da teoria da gerência científica, desenvolvida por Frederick Taylor, que Bell entendia ser a provável maior responsável pela instauração de modelos técnicos na atividade industrial e, como tal, uma das grandes patrocinadoras da concepção tecnocrática segundo a qual as "coisas conduzem os homens" (Bell,1973, p. 352). As experiências de Taylor começaram a ser conhecidas em fins do século 19. Em 1903, ele divulgou uma memória sobre a organização científica nas oficinas e, em 1911, publicou seus Princípios de administração científica, proporcionando a mudança de direção decisiva e definitiva no comportamento do empresariado americano e, ao que tudo indica, abriu o caminho para a penetração das ciências sociais na estratégia empresarial. De acordo com Baritz (op. cit., p. 60-1), a substância da noção de gerência científica se estabelecia a partir da idéia de que o sistema produtivo deveria obedecer a determinadas normas e ser funcional. A maneira de colocar esta diretiva em prática era a subdivisão das tarefas nas menores unidades de tempo e movimento que fossem possíveis, para combiná-las como métodos de "gastos mínimos". As destrezas no trabalho transferiam-se do trabalhador para o empresário, que as analisaria e as devolveria ao trabalhador em parcelas de modo que "os trabalhadores jamais voltariam a ser mestres em seus ofícios". O aperfeiçoamento do método taylorista, de início comparado por ele mesmo, em conferências que proferiu em Harvard por volta de 1909, a uma organização militar, operar-se-ia por intermédio de uma aliança com a psicologia experimental, inspirada em testes desenvolvidos pelo psicólogo alemão Hugo Münsterberg (Giedion, 1978, p. 114-5). 
Outro passo seria dado por Henry Ford. Segundo o texto de Baritz (op. cit., p. 67-72), baseado em historiadores que se dedicaram a estudar a vida de Ford, ele se teria dado conta do valor dos homens, em 1912, em meio a um período de turbulência da economia do país. A famosa jornada de cinco dólares causou sensação no meio industrial e foi justificada por Ford como uma participação do trabalhador nos lucros da empresa. Seguiuse a isso a criação de um departamento sociológico cujos integrantes se dedicavam a investigar a vida que os empregados levavam em casa, observando se seu comportamento era adequado e se sua vida íntima era sadia. O grande sucesso de Ford não sobreviveu à crise que se instalou durante a Primeira Guerra e à depressão no pós-guerra, mas, sem dúvida, teria comprovado seu ponto de vista, segundo o qual se o empresário dedicasse maior atenção ao elemento humano de seu negócio, veria aumentar a produção e o lucro em maior proporção do que se o fizesse através da introdução de novas máquinas. Apesar disso, a sua lição serviu para atrair a atenção do empresariado para a importância da inversão em homens, "que um cuidadoso estudo deste fator humano era um bom negócio".

Em meio à depressão de fins dos anos 20, ocorre uma experiência decisiva no sentido de encontrar as condições ideais de controle e manipulação do fator humano na produção. Foi a investigação realizada pelo departamento Hawthorne Works, da Western Eletric Company, o maior projeto levado a efeito no meio industrial do Estados Unidos, envolvendo orçamento de mais de um milhão de dólares. Tal programa, na avaliação de Bartiz, influenciou profundamente a ciência social e se converteu em marco dos estudos de sociologia industrial, definindo um campo de trabalho e investigação de grande repercussão no meio industrial, o das relações humanas. ${ }^{1}$

A utilização da psicologia no estudo do comportamento industrial desenvolveu-se no curso da Primeira Guerra, aproveitando análises realizadas por psicólogos para as forças armadas do país. Imediatamente após

1 Baritz descreve o experimento de Hawthorne Works, nos capítulos 5 e 6 de seu livro. Sobre esse experimento e sua importância, ver também Burrel \& Morgan, 1998 [1979], p. 130-143). 
cio a uma fase de grande impulso nos estudos de psicologia aplicada, justificados pelo reconhecimento de uma suposta desorganização industrial. O objetivo principal destas análises era, em essência, ajustar os indivíduos e antecipar suas reações aos perfis de operários imaginados pelos patrões. O "experimento de Hawthorne", conduzido pela Harvard Business School, sob a direção de Elton Mayo, concluiria, após vários anos de análises, que elas não produziam resultados satisfatórios. A conclusão da equipe de Mayo foi de que a motivação dos trabalhadores não podia ser avaliada a partir de informações individuais, e que o entendimento do seu comportamento tinha que ter como base os grupos sociais com os quais o trabalhador se relacionava na fábrica. Segundo Mayo, a organização dos trabalhadores era irracional, e a solução dos problemas referentes à falta de lealdade dos trabalhadores para com a direção somente poderia ser eliminada através da "melhor compreensão". Essa solução deveria realizar-se através de uma mudança de diretriz dos estudos, da psicologia para a sociologia. O enfoque das "relações humanas", que na realidade unia psicologia e sociologia, seria o embrião de uma série de experiências em torno do comportamento social.

A influência das experiências de Mayo e sua equipe diminuiria sensivelmente com a depressão e a emergência do sindicalismo em Hawthorne. No contexto da Segunda Guerra, a necessidade de controle e orientação das forças armadas americanas ensejariam novo momento de ascensão dos estudos sobre relações humanas. De 1946 em diante, assinala Baritz (op. cit., p. 314 e 318), a convicção empresarial da importância das questões relativas às relações humanas era ilimitada. Em 1954, a aceitação da ciência social se converteria em excelente negócio, na medida em que ela se tornava "essencial para vida industrial".

Martin Nicolaus (1982, p. 46-7) assinala que um projeto de pesquisas realizado com soldados no período do conflito, publicado posteriormente com o título The american soldier, daria origem a uma organização 
de pesquisas sociológicas que teria grande projeção no país. A Sociedade Sociológica Americana mudou, em 1958, seu nome para Associação Americana de Sociologia e instituiu uma nova modalidade de formação profissional, voltada para o desenvolvimento de pesquisas tecnologicamente sofisticadas com o fim de produzir resultados de interesse para os compradores das corporações e do governo. O ritmo do crescimento das ciências sociais aplicadas cresceria de forma extraordinária nessa época. Isso foi resultado, diz Gouldner, de um incremento em investimentos promovidos pelo Governo com a finalidade de desenvolver, de forma politicamente orientada, apoio a atividades de ajuda social, de desenvolvimento bélico e industrial. Gouldner exemplifica mostrando que, em investigações na área da sociologia e nas ciências sociais em geral, foram investidos, em 1962, 118 milhões de dólares; em 1963, 139 milhões, e, em 1964, 200 milhões (1973, p. 318).

A expressão capital humano pertence seguramente à década de 1950, parece não haver dúvidas quanto a isso. Entretanto, quando se começa a examinar a bibliografia que informa o texto de Baritz, verifica-se que a produção de estudos envolvendo a questão do elemento humano na produção industrial cresce e se diversifica a partir da perspectiva das ciências sociais, no período de 1913 a 1920. É nesse momento que se observa a emergência da discussão sobre a importância do comportamento humano no trabalho, com o sentido de torná-lo "inteligível e mais propício ao controle", como manifesta um autor citado por Baritz (op. cit., p. 53, n. 1). Expressões tais como "engenharia humana", "elemento humano na indústria", "gerência de seres humanos", "seleção científica de empregados", datam dessa época. Significativamente, todos os estudos publicados nos Estados Unidos ali referidos são posteriores à divulgação dos estudos de Frederick Taylor. De outro lado, Gary Becker, ao definir os créditos de seu trabalho sobre capital humano (1983, p. 27, n. 2), refere, além do texto de Schultz, de 1961, as análises de Friedman e Kusnets, Income from indepedent 
professional practice (1945), de H. Clark, Life earnings in selected occupations in the U. S. (1937), J.R. Walsh, Capital concept applied to man" (1935) e G. Stigler e D. Blank, The demand and supply of scientitic personnel (1957). Sobre o crescimento do interesse pelos estudos em torno da questão, Becker anota que a bibliografia sobre o tema, em 1957, somava menos de cinqüenta títulos publicados; em 1964, registravam-se cerca de 450 títulos, e, em 1970, mais de 1300 (ibid., p. 13).

Utilizando Gary Becker como elemento de referência, a idéia de capital humano desponta, nos estudos de Bell, como sinônimo de conhecimento técnico, com a educação assumindo caráter de investimento e função estratégica na definição dos princípios axiais da estrutura da sociedade pós-industrial (op.cit., p. 118, Tabela 1-2; p. 410-1). A trilha desta construção teórica passa, sem dúvida, pelas contribuições de Frederick Taylor em torno da organização científica do trabalho.

Para os objetivos deste estudo, é irrelevante a polêmica que envolveu a estratégia de modelos pré-definidos de organização do trabalho que o taylorismo, primeiro, e sua combinação com o fordismo, depois, representaram para a determinação do desenvolvimento econômico e industrial americano e mundial. A contribuição de Taylor será tomada aqui em relação ao seu conteúdo teórico enquanto modo de pensar o universo do trabalho industrial, colocando em prática um método de organização do trabaIho que, conforme a observação de Lukacs, realiza "a decomposição 'psicológica' do processo de trabalho" e que, ao penetrar "a alma do trabalhador", impõe o "princípio da racionalização baseada no cálculo" (1974, p. 102). É possível identificar nos argumentos de Taylor sobre esse processo de racionalização elementos de uma perspectiva importante para a elucidar a origem da teoria do capital humano em seus desdobramentos posteriores, tanto no campo da teoria da organização empresarial, com a difusão da produção em massa através da articulação taylorismo-fordismo quanto na conformação do determinismo tecnológico que tenderá a dominar a con- 
cepção de sociedade do conhecimento e que impressionará definitivamente o campo da teoria sociológica quanto o da teoria econômica.

A ciência em lugar do empirismo, a harmonia em lugar da desavença, o espírito de equipe em vez de individualismo, o rendimento ótimo ao invés de rendimento deliberadamente insuficiente, o aperfeiçoamento de cada homem para alcançar eficiência e prosperidades máximas, são os cinco princípios que coroam a concepção de gerência científica (Taylor, 1963, p. 126-7). Esses cinco princípios podem ser reunidos em duas questões fundamentais para a consagração do modelo de organização do trabalho desenvolvido por Taylor. A primeira questão diz respeito à necessidade de estabelecer uma fórmula de disciplina de trabalho que enseje ao empresário o controle do trabalhador. A segunda, com base na primeira questão, é garantir o controle do conhecimento do trabalhador. Como comentou Gramsci em uma de suas muitas incursões sobre o taylorismo, não existe trabalho físico puro, a própria expressão "gorila amestrado" usada por Taylor, para definir o tipo de operário ideal da organização industrial. "é uma metáfora para indicar um limite numa certa direção" (2000, v. 2, p. 18).

Esse limite é, na realidade, definido pela apropriação do conhecimento do trabalhador, ou, melhor dizendo, pela transferência do controle da inteligência do trabalho para a gerência. Taylor percebe muito bem que o desenvolvimento técnico da atividade produtiva não se resume a problemas restritos ao plano dos instrumentos, ou à invenção e à inovação sistemáticas, como havia ocorrido na sociedade americana, no último quarto do século 19. Sua preocupação voltava-se para a transformação do homem em máquina que trabalha, através da organização e do disciplinamento do processo de trabalho. A propósito da relação do taylorismo com as ferramentas, Coriat (1976, p. 96-97) anota que, como método de extração de mais valia relativa, a organização científica do trabalho se encontra com as ferramentas geralmente como um obstáculo ou, pelo menos, como algo não adequado aos seus objetivos e, nesse sentido, Taylor irá propor a seleção e outros desenhos de ferramentas, com sua adaptação aos diferentes tipos de atividades. 
Em seu livro sobre os princípios que deveriam reger a administração científica, Taylor, havia descrito como se verificava a criação de uma ciência da gerência, contrastando este processo com o sistema de gerência usado no passado. Tratava-se de uma atividade que implicava a definição de muitas normas, leis e fórmulas que só poderiam funcionar adequadamente se devidamente organizadas e sistematizadas, pelo administrador, dissociandoas da experiência dos operários. O emprego de informações científicas assim processado exigia também um local apropriado, diferente do espaço da oficina onde os operários atuavam, local esse em que se realizariam os projetos e os planos das atividades de trabalho diárias, com as tarefas e sua forma de execução discriminadas passo a passo com pelo menos um dia de antecipação. Em 1912, Taylor seria levado a depor perante uma Comissão Especial da Câmara de Representantes sob a alegação de tratar os homens como máquinas e fazer da produção máxima o grande objetivo da empresa, ao invés de cuidar da segurança e da satisfação dos operários. Taylor prestou um longo depoimento, procurando justificar a adoção de seus métodos. Disse ele, na parte mais substantiva de sua argumentação: ${ }^{2}$

Desejo tornar claro (...) que um trabalho desse tipo empreendido pela gerência leva ao desenvolvimento de uma ciência, ao passo que é quase impossível para o operário desenvolver uma ciência. Há muitos operários que são intelectualmente capazes de desenvolver uma ciência, que têm cérebro, e são perfeitamente capazes de desenvolver uma ciência como os que trabalham na administração. Mas a ciência de fazer trabalho de qualquer espécie não pode ser desenvolvida pelo operário. Por quê? Porque ele não tem tempo nem dinheiro para isso. (...) Se coubesse a qualquer operário descobrir um meio novo, ou se Ihe coubesse revelar um novo método, os senhores podem perceber imediatamente que se

2 As declarações de Taylor são extraídas de seu testemunho à Comissão referida, tal como vêm reproduzidas em duas fontes: no livro Trabalho e capital monopolista, de Harry Braverman, e do texto organizado por José Luiz Orozco, El testimonio político norte-americano: 1890-1980). 
tornaria de seu interesse guardar o descobrimento para si mesmo e não ensinar a outro o método mais rápido. É de seu interesse fazer o que os operários sempre fizeram, guardar os segredos do ofício para si mesmos e para seus amigos. Esta é a velha idéia de segredos de ofício. O operário guardava seu conhecimento para si mesmo em vez de desenvolver uma ciência e ensiná-la a outros, tornando-a propriedade pública (Braverman, 1981, p. 105-6; 115-7) (grifo RPS).

Na apreciação de Braverman, Taylor revelava com clareza a extensão do poder do capital, mostrando que não somente o capital era propriedade do capitalista, "o próprio trabalho tornou-se parte do capital". Para Braverman, Taylor, melhor do que ninguém, havia compreendido o princípio de Babbage (1830) sobre a divisão do trabalho mental. Estudar o processo de trabalho não tinha como meta enriquecer a capacidade do operário ou fazer dele sujeito do conhecimento científico, ou, ainda, que ele aumentasse sua capacidade com o incremento técnico. O objetivo era simplesmente fazer baixar o custo do trabalho, diminuindo seu preparo e fazendo-o aumentar a produtividade (1981, p. 107). Isso parece ser contraditório em relação à teoria do capital humano, mas, na realidade, não é.

A interpretação de Braverman pode ser complementada com a análise do método de Taylor realizada por Alfred Sohn-Rethel (1980, p. 152 e 153). Ponto decisivo na fórmula taylorista de organização do trabalho, observa Sohn-Rethel, é o fato de que a mensuração do tempo de trabalho e a definição dos ritmos de realização do trabalho não são obtidas empiricamente, através da observação da atuação dos trabalhadores na realização das tarefas. Os tempos e movimentos são definidos como normas de trabalho às quais os trabalhadores deverão adaptar-se. A coerção temporal, ou seja, o minucioso controle do tempo, é condição principal da ciência da administração empresarial. Os conceitos de tempos e movimentos são utilizados como "categorias tecnológicas" e não considerados em termos de trabalho 
humano. Assim, na concepção de Taylor, diz Sohn-Rethel, o trabalho humano é "transformado em uma entidade tecnológica, homogênea à maquinaria e diretamente adaptável a ela, podendo ser incluído e transformado nela sem nenhum dificuldade". A submissão econômica da força de trabaIho ao capital é complementada com a sua submissão física e tecnológica. Este é o ponto de partida do "processo que nos leva à automatização do trabalho humano no sentido técnico preciso do termo".

Em outra oportunidade, Sohn-Rethel, reforçou suas observações nesse sentido. As medições do sistema Taylor derivavam da parte mecânica e tecnológica das atividades consideradas. Dessa forma, os estudos de tempos e movimentos realizados com sucesso representavam a fusão de tecnologia e trabalho, "os movimentos da máquina são medidos em termos de trabalho e os movimentos do trabalho em termos da máquina". Deste modo, o princípio da "socialização estrutural do trabalho, partindo de uma simples gradação em menor ou maior, ganhou a qualidade de uma nova lei econômica" (1982, p. 47). Isto é, as condições de reintegração do trabalho atomizado na produção não obedeciam aos padrões de valor da troca de mercadorias. A produção em massa por meio do fluxo contínuo, introduzida por Henry Ford, em 1922, iria acrescentar um dado crucial a essa equação.

Os pontos levantados por Sohn-Rethel, a respeito do sistema fordista combinado com o sistema taylorista, destacados a seguir, são fundamentais para estabelecer a provável linha de articulação entre esta "socialização estrutural do trabalho" e a teoria do capital humano.

Em conformidade com a análise de Sohn-Rethel, a contribuição essencial da correia de transmissão

é a fixação de um padrão de ritmo comum a todas as operações parciais, ou a seus elementos manuais. (...) A razão da significação econômica inerente à sua função reside na combinação de máquinas e trabalho efetuada pela correia, na ligação das funções manuais dos 
trabalhadores com as funções da máquina. com base na unidade de medida de ambas. (...) A igualdade de ritmo imposta pela correia recai sobre os trabalhadores como um fato consumado (op.cit., p. 48).

Na situação anterior da organização do trabalho, com o trabalho individual executado em processos produtivos que não se relacionavam mutuamente, a falta de ligação na produção devia ser compensada por alguma forma de comunicação que supunha um relacionamento entre os trabalhadores e a indústria com base em propriedades, ou seja, "entre todas as pessoas enquanto proprietários privados". No sistema taylorista-fordista, a forma de organizar o trabalho alterava-se substancialmente. Então a

socialmente indispensável quantificação e medida do trabalho e do tempo de trabalho ocorrem indiretamente e não em termos de trabalho, mas em termos da enigmática categoria do valor (...). Fundamental a essa estrutura é uma direta quantificação e mensuração do trabalho efetuado no processo de trabalho da produção, e em seus próprios termos. É uma medida não do trabalho em si, mas do trabalho em conjunto com a tecnologia - e dela dependente - com a qual se combina na produção, e em resposta à fórmula da unidade de medida das funções humanas e tecnológicas em sua aplicação produtiva combinada. Esta fórmula permite $O$ uso da automação (ibid., p. 48-49).

O tempo de trabalho, que era um valor social porque era medido, não pelo tempo de trabalho efetivo que exigia do trabalhador individual para produzir determinado objeto, mas pelo tempo socialmente necessário para a sua produção, definindo a magnitude de valor desse objeto, no sistema de Taylor e Ford, essa avaliação do tempo trabalho socialmente necessário passava a ser feita com base na relação entre trabalho e tecnologia. O tempo de trabalho socialmente necessário passa a ser um tempo cientifica- 
mente estabelecido, fora do processo de trabalho. É nesse sentido que o trabalho estruturalmente socializado terá a força de uma "lei econômica".

Taylor tinha a convicção, e reiterava isso em diferentes momentos, de que ele havia proporcionado uma transformação decisiva para a sociedade industrial, não apenas com a criação de uma ciência do trabalho, mas a operacionalização de uma verdadeira revolução nas relações entre capital e trabalho. Geralmente subjacente à enumeração das vantagens do seu sistema, em Os princípios de administração científica está a idéia de que ele proporcionava relações mais amistosas entre a administração e os empregados. No depoimento prestado à Comissão Especial da Câmara de Representantes, Taylor estabeleceu um paralelo entre a experiência passada e o seu método, sustentando que, no passado, a inteligência e o interesse de administradores e operários se fixava no que se poderia chamar de uma "apropriada divisão do plusproduto resultante dos esforços conjuntos". Seus princípios haviam, entretanto, proporcionado uma revolução na atividade mental, nas duas partes envolvidas na administração científica, fazendo com que elas deixassem de ter a apropriação do excedente como principal preocupação e se voltassem para a busca do incremento desse excedente, de modo que ele se tornasse de tal monta que resultaria desnecessário realizarem-se disputas sobre a forma como seria dividida. Taylor complementa suas observações sobre a "revolução mental" posta em curso pela administração científica de que patrocinaria a "substituição da vigilância receosa pela confiança mútua, a conversão da inimizade em amizade" (Apud Orozco, 1982, p. 133-4).

A forma como Taylor argumenta em sua defesa perante a Comissão é expressiva de um esforço para amenizar a crueza com que expôs suas teorias sobre a administração dos negócios. Suas idéias sobre crescimento econômico, observa Coriat (1994, p. 33), tinham em perspectiva uma transformação substantiva nos velhos costumes de condução da economia de um modo geral e não apenas das fábricas. Em muitas ocasiões, suas obser- 
vações eram contundentes e desmistificadoras das relações entre capital e trabalho. Algumas frases extraídas por Coriat de uma coletânea de textos de Taylor revelam uma clara percepção da importância de seus estudos e uma ingenuidade extremamente angustiante para seus pares. ${ }^{3}$ Eis algumas dessas frases: "A fonte da riqueza não constituída pelo dinheiro, mas pelo trabalho (...) A riqueza provém de duas fontes. Em primeiro lugar, do solo e do que se encontra no solo e, depois, do trabalho do homem (...)".

Quanto à necessidade de aumento de produtividade para a acumulação de capital, antecipando críticas e projetando um futuro inexorável Taylor sustentava:

Estas mudanças (da produtividade) são o que interessa ao pobre, as que Ihe dão mais alto nível de vida e transformam os objetos de luxo de uma geração em objetos de primeira necessidade para a seguinte. (...) Qualquer que seja a oposição e de quem quer que venha, qualquer que seja a sua forma e a sua importância, todo dispositivo que permita economizar trabalho acabará impondo-se; este é um fato histórico" (Apud Coriat, citado, p. 34 e 35).

Nos Estados Unidos, a subsunção real do trabalho ao capital (para usar termos da análise marxiana), ou a socialização objetiva do trabalho (para usar a terminologia de Ernest Mandel), se concretizará na medida em que o taylorismo e sua concepção de eficiência se expandirem, tanto em relação ao processo de trabalho quanto ao controle do conhecimento do trabalho. Isto é, o modo de realizar a "revolução mental" pretendida era a apropriação, ou "publicização", nos termos de Taylor, do conhecimento dos trabaIhadores. Este processo ganharia ainda maior extensão e profundidade com a contribuição de Henry Ford.

3 Origem das frases, segundo Coriat, é a edição das obras principais de Frederick Taylor, Scientific Management, publicada por Greenwod Press, Wesport, Connecticut, 1972. 
Hilferding (1973, p. 344 e 350), registrou, no início do século 20, que a união entre o capital industrial e o bancário converteu-se num dos fatores mais importantes para estimular formas de organização mais sofisticadas na Alemanha e nos Estados Unidos. Neste último país, em razão do seu vasto espaço econômico, a fusão patrocinou grande especialização de estabelecimentos e um desenvolvimento industrial extraordinariamente rápido. No período de 1910-1930, a projeção do taylorismo e do fordismo define o primeiro momento de crescimento exponencial da produção em massa. Segundo Coriat (1976, p. 141), este momento é marcado por alguns acontecimentos decisivos na configuração da economia americana e mundial: a intensificação do processo de trabalho e da escala de produção não encontra paralelo em outras épocas, a nova organização do trabalho alcança a produção de meios de subsistência da classe trabalhadora e o salário experimenta elevação importante, tanto nominal quanto real. ${ }^{4}$

A vulnerabilidade deste crescimento ficaria evidente em fins da década de 20, mas a combinação taylorismo-fordismo seria ponto fundamental do desenvolvimento do capitalismo definitivamente. Braverman dedica todo um capítulo (capítulo quinze) para mostrar como o taylorismo, à época de Taylor, não através dele, mas de seus seguidores, passou a ser aplicado em escritórios. É o caso do livro de William Henry Leffingwell publicado em 1917 e o de Lee Galloway, um ano depois, também tratando da aplicação dos princípios da gerência científica no escritório. Na segunda metade do século, com a mecanização, os trabalhos de escritório tenderiam a experimentar os mesmo processos de controle e fragmentação de tarefas utilizados nas oficinas, acrescentando-se ao processo o controle da informação. Com a introdução do computador e a sua rápida difusão, a fragmentação de tarefas e o processo de destruição dos ofícios se aceleraram, inclusive aqueles que apareciam em função da nova máquina no escritório. 
O computador ainda não existia na época de Taylor. Entretanto, como comenta Paola Manacorda (1976, p. 35), com sua contribuição ao desenvolvimento das técnicas de cálculo e a aplicação dessas técnicas à organização do trabalho como que preparam o terreno para sua utilização, "quase que se poderia dizer que, se Babbage é o inventor do computador, Taylor é o inventor do sistema de informação". Em meados dos anos 70, porém, os robots começam a ser instalados em lugar dos homens. Depois de reconhecer o papel fundamental da gerência científica na expropriação do trabalhador, Coriat (1985, p. 51-52 e nota) busca mostrar como esse processo começa a caducar. O robot "confisca" e se "apropria" dos processos de operação realizados pelos operários, sem que eles tenham sido antecipadamente reduzidos a movimentos e tempos elementares. "O robot confisca 'em bloco', por 'seqüências inteiras' o conjunto do conhecimento do operário para voltar a restitui-lo como tal". Mas efetivamente caducaram os princípios organizativos empresariais estabelecidos por Taylor e desenvolvidos por Ford?

O coração do seu ensinamento (de Taylor) segue presente e bem vivo no centro dos dispositivos complexos supostamente mais modernos e mais sofisticados. (...) Se o robot ou o computador são indiscutivelmente suportes (...) para tornar operativas novas organizações (...) em nenhum caso constituem substitutos da atividade propriamente conceitual em que consiste o ato de conceber uma organização do trabalho e da produção. Taylor e posteriormente Ford foram importantes por suas contribuições em conceitos, ou se se quiser por suas inovações organizacionais (Coriat, 1996, p. 19 e 20).

Se seguirmos a análise de Bell sobre a sociedade pós-industrial, é impossível pensar o extraordinário crescimento do sistema educacional americano e a caracterização de uma sociedade da informação ou do conhecimento, sem considerar o crescimento veloz da economia do país no 
começo do século 20. E, portanto, é impossível pensar esses acontecimentos sem envolver o taylorismo e seus desdobramentos como fator nuclear da sua verificação. Em uma das raras referências a Taylor, Daniel Bell (1973, p. 351) sustenta ser ele um dos responsáveis para a transição para o estilo tecnocrático nas práticas industriais. Sua idéia de que o status devia basearse em conhecimento superior e não no nepotismo ou no poder financeiro, seria o exemplo definitivo de que a influência e a liderança deveriam se basear fundamentalmente na competência técnica.

A busca dessa competência se viabiliza através da conexão entre as universidades americanas e o grande empresariado reunido nas corporações. O depoimento de Michael Perelman (2002), é realmente impactante a respeito desse comprometimento do processo educacional americano com as necessidades empresariais. Para deixar clara essa conexão, Perelman (2002, cap. 3) indica que as soluções relativas à sua consolidação datam de fim do século 19. Lembra que é dessa época o surgimento de Silicon Valley, região sede da moderna indústria de computação, que teve como elemento crucial de seu desenvolvimento a combinação da pesquisa científica com o mundo corporativo. Perelman também refere os estudos históricos de David Noble a respeito do surgimento e crescimento do Instituto de Tecnologia de Massachusetts em articulação estreita com o setor industrial. Perelman traz também à consideração o protesto de Thorstein Veblen, publicado em 1918, contra a excessiva intervenção do mundo dos negócios na vida acadêmica. Cita os casos Andrew Carnegie e John Rockfeller que, no início do século 20, apoiaram e sustentaram o projeto educacional de Henry S. Pritchett, cujo propósito central era, utilizando o exemplo do "especialista em eficiência", Frederick Taylor, pressionar as instituições universitárias a adotarem procedimentos adequados às práticas do gerenciamento empresarial. A criação do General Educational Board, por John Rockfeller, em 1903, injetaria no sistema educacional americano, com propósitos idênticos, cerca de 53 miIhões de dólares de uma dotação total do sistema de 259 milhões. 
O depoimento de Perelman prossegue mostrando o crescimento dessa tendência nos momentos posteriores. Nos anos recentes, as universidades reinventam-se a si mesmas para tornar-se mais parecidas com as corporações, em sua meta de fazer "science cum business" (ibid., p. 88).

David Noble (2002), focalizando os métodos empregados nas atividades de educação à distancia em desenvolvimento em instituições de ensino americanas e operados via internet (online education), afirma que não se pode imaginar esta transformação sem ver em seu coração, "a taylorização do trabalho de instrução, na qual a função do ensino é repartida em componentes discretos e destinados a diferentes trabalhadores". Noutro ponto, Noble reproduz a fala do presidente da New York State University Professions que descreve o que está ocorrendo como um movimento de "desmonte e desqualificação da profissão". Fato que, em pouco tempo, irá reproduzir-se, com toda segurança, na geração futura de profissionais do trabalho acadêmico, comenta Noble.

Recuando ou avançando na história do processo industrial, a questão da "economia de tempo" é um imperativo do processo não só de produção, no sentido estrito, mas também de adequação geral das comunidades urbanas à nova disciplina de vida e de trabalho. Fato reconhecido nos primórdios da revolução industrial (Thompson, 1984) ou na sociedade americana, desde fins do século 19 em diante (vide Braverman, op.cit., parte 5, cap.20). É de certo modo surpreendente que, dadas todas as evidências existentes, Mark Blaug, que é um dos principais especialistas em temas relacionados à economia da educação, não faça menção alguma aos processos que envolveram a economia americana desde finais do século 19 e que tiveram em Frederick Taylor o personagem central. O programa de pesquisa científica cujo núcleo é o capital humano, tem um conteúdo bem definido, mas não tem gênese conhecida, de acordo com Blaug. Conhecem-se seus "pais fundadores", que não se deram conta da paternidade, e os seus arautos modernos: Schultz, Mincer, Becker (todos americanos). Esta 
posição não é exclusividade de Blaug. Há uma tendência à omissão, quase que total, à contribuição de Taylor e do taylorismo e dos estudos envolvendo a articulação das ciências sociais na organização do trabalho industrial no que respeita ao processo de formação da teoria do capital humano. Um caso extremamente sugestivo dessa omissão é a Enciclopédia Internacional de Economia da Educação, editada por Martin Carnoy (1995).

A afirmação de Blaug relativa à condição da teoria do capital humano como um subprograma de um programa neoclássico mais amplo e de que, na raiz, ela consista "simplesmente na aplicação da teoria normal do capital a certos fenômenos econômicos" (1985, p. 251), é uma maneira um tanto ligeira e inconseqüente de tratar as condições reais de emergência da noção e do sentido que ela adquiriu na sociedade contemporânea.

David Dickson (1980, cap. 3) menciona o fato dos novos estudos de história econômica, realizados em torno da revolução industrial, terem revelado que o aumento do valor da produção era, no período, consideravelmente maior que as inversões em terra, trabalho e capital, juntos. Tal fato devia ser atribuído à contribuição da perícia técnica e do conhecimento, normalmente não creditados no aumento do valor produzido. Sobre a possibilidade de esse incremento derivar da incorporação de novas máquinas à produção, Dickson argumenta que isso só poderia ser considerado como uma conseqüência da implantação de modelos cada vez mais autoritários na condução do processo de trabalho e na sua organização. Isto é, seria resultado do desenvolvimento do processo de racionalização tal como examinado por Max Weber. "Concretamente" - afirma Dickson apoiando-se no texto de Theodore Schultz publicado pela American Economic Review, de 1962 - "isto foi conseguido por meio de um sistema educativo destinado a produzir o 'capital humano' que encaixaria tanto no marco técnico como disciplinar do novo sistema fabril" (ibid., p. 65). O marco técnico e disciplinar do sistema fabril, aludido por Dickson, está, certamente, fundado na contribuição de Taylor. 
A resistência em identificar as diferentes tendências que começam a se manifestar na sociedade americana desde fins do século 19, que se acentuam no começo do século 20 com a discussão sobre a caracterização de esforços dedicados à educação formal e ao trabalho, à saúde e outras formas de buscar uma adaptação à sociedade urbana e industrial, e se consolidam na teoria do capital humano parecem ter sua fonte num dilema político que envolve a tradição liberal e individualista da sociedade americana e seu comprometimento no processo de reorganização econômica do país, em face das novas condições do mercado mundial. Esse dilema se apresenta concretamente nos trabalhos de Frederick Taylor e nos estudos de Adolf Berle Jr. e Gardiner. ${ }^{5}$ São duas faces, mas um mesmo dilema.

A concepção de administração científica de Frederick Taylor revelou aos americanos e ao mundo, ademais de uma forma de socialização do trabalho, o ângulo cruento do processo de "enriquecimento do trabalho" que se escondia sob ideologia da racionalidade científica. Além de autocrático e subversivo ao declarar a necessidade de ver no trabalho a real fonte da riqueza e do tecnocrata como instrumento decisivo da apropriação do conhecimento do trabalhador, desagradava tanto aos empresários (que não obstante, aceitavam a "filosofia social" de Taylor), quanto aos trabalhadores reunidos em sindicatos, que viam na gerência científica a intensificação da exploração e da opressão do capital. De forma aguda e definitiva, Taylor agredia e desafiava o paternalismo cristão subjacente aos esforços de "humanização" do trabalho das fases antecedentes do desenvolvimento industrial. De certo modo, Taylor ia em direção contrária à de Ford, que promovia novamente o empresário (Altvater, 1995, p. 85-6), reafirmando a nor-

5 Adolf A. Berle e Gardirner C. Means, o primeiro, jurista e o segundo, economista, difundiram, no começo da década de 1930, dois estudos sobre a corporação. O verbete Corporation da Enciclopédia de Ciências Sociais (1967, p. 414-23) e o livro intitulado Propriedade privada na economia moderna (The Corporation and Private Property). A tese central de ambos os textos é desenvolvida em torno da idéia de que, nas empresas de grandes dimensões, manifesta-se uma nítida separação entre a propriedade, dispersa nas mãos de milhares de acionistas, e o controle, concentrado nas mãos de poucos que a administram e tomam as decisões. De acordo com os autores, o sistema fabril teria produzido a separação entre controle e trabalho, o sistema corporativo (sociedades por ações) teria realizado a separação entre controle e propriedade. Este processo teria dado origem a uma nova perspectiva para o conceito de propriedade (ver a respeito, Saul, 1990a). 
ma da necessidade de as empresas realizarem o "máximo lucro através do máximo de produção com o mínimo de custo", sua grande e original contribuição ao mundo dos negócios, de acordo com Drucker (1946, p. 220).

Mas, se o taylorismo pode ser visto como uma resultante da grande depressão dos anos 1873-1890 e seus métodos representem, de 1918 em diante, o uso racional das máquinas e da força de trabalho no planejamento, tanto entre os bolcheviques quanto entre os capitalistas, conforme assinalaram vários autores, entre os quais Bell (1973) e Hobsbawm (1988), a teoria da corporação desenvolvida por Adolf Berle Jr. e Gardiner Means pode ser considerada produto de dois eventos, próximos no tempo e distantes no espaço mas contidos na mesma dimensão geopolítica, a planificação soviética de 1928 e o "great crash" de 1929.

A tese de Berle e Means sobre a natureza da propriedade no sistema corporativo projeta, no contexto da crise dos anos 30, uma perspectiva política nova e marcada por uma equação jurídica bastante problemática: o poder sem propriedade e a propriedade sem poder. Trata-se de uma espécie de atualização do velho dilema que fez tremer os princípios republicanos ainda nos seus primeiros momentos de vida, na França, e foi resolvido por meio da contraditória fórmula da "propriedade como condição da liberdade". Dilema, que antes dos republicanos franceses, foi vivido intensamente nos escritos dos federalistas americanos em suas vacilações a propósito da sustentação de um conceito de propriedade no sentido amplo, das liberdades espirituais, como a liberdade política, a liberdade de pensamento e de comunicação, além das propriedades materiais, terras, mercadorias, dinheiro, e uma concepção de propriedade restrita aos bens materiais.

Por trás da fórmula "poder sem propriedade-propriedade sem poder", na realidade, Berle e Means lançavam diante da sociedade americana, entretecida na filigrana teórico-jurídica da sociedade por ações, a "nova" lógica da propriedade capitalista, travestida de lógica socialista made in USA. Embora jamais seja mencionado nesses textos o nome de Frederick Taylor, 
parece perfeitamente claro que os argumentos desenvolvidos pretendem reverter o clima opressivo criado pelo sistema taylorista e sua sustentação da necessidade de apropriação do conhecimento do trabalhador, colocando-o sob a regência da administração cientifica, como condição para manter sob controle o fator decisivo da riqueza, o trabalho. Assim fazendo, Berle e Means produziam dois efeitos contraditórios: por um lado indicavam as profundas implicações que o taylorismo tinha na extensão do processo de racionalização a todas as instâncias da vida em sociedade e, por outro, afirmavam o caráter polar que o conhecimento adquiria no interior desse movimento. Construindo a configuração jurídica de uma situação em que a expressão principal do poder desprendia-se da propriedade, Berle e Means definiam, no mesmo momento, o caráter estratégico que o saber possuía nas relações de propriedade da sociedade capitalista. Berle e Means davam forma jurídica ao processo que Taylor havia descortinado para o empresariado americano, a nova sede do poder: a propriedade do saber.

Quando se examina um texto seminal da teoria do capital humano, como, por exemplo, o texto de Theodore Schultz divulgado na The American Economic Review de março de 1961 se é levado a crer que as questões relacionadas com a necessidade de rever o conceito de capital com fim de adequá-lo aos novos tempos é coisa que os economistas clássicos ensaiaram, mas não resolveram, e que os economistas contemporâneos aproximavam-se da questão mas não conseguiam defini-la adequadamente ou simplesmente se mostravam incapazes de fazê-lo.

Entretanto a percepção de que ocorrera uma mudança substantiva na concepção de capital é parte fundamental das teses sustentadas por Berle e Means, desde os anos 1930. Ademais, é preciso considerar os desenvolvimentos teóricos da sociologia, de modo especial a partir dos anos 1940, na configuração da teoria da estratificação social como fator distintivo das relações sociais emanadas das "novas" relações de propriedade que se constituíam a partir da organização das empresas formadas por capital acionário. 
A constatação da possibilidade de construção de uma noção de capital mais ampla e abrangente do que a usada pelos economistas emerge quase que naturalmente neste contexto. É ilustrativa nesta perspectiva a teoria da propriedade desenvolvida por autores americanos desde os anos 40, sob a inspiração dos textos de Max Weber (Ver, por exemplo, Parsons, 1940; Davis \& Moore, 1981 [1945]; Parsons \& Smelser, 1965, Cap. 3 e 4 ).

O próprio Adolf Berle Jr., em texto, datado originalmente de 1959, no qual ataca a tradição liberal americana e reforça a teoria desenvolvida no início dos anos 30, ampliando as observações sobre a nova estrutura do poder, desenvolve a mesma crítica ao conceito de capital tal como usado pelos especialistas da área, que, entre outras limitações, não distinguiam entre consumo e gastos produtivos (Berle Jr.,1961, cap. I).

Não estava longe disso Peter Drucker quando, em seu estudo sobre a corporação, criticando a crença de Henry George de que a apropriação de nova terra era a fonte do capital, sustenta que a "única fonte do capital é o lucro" (1946, p. 233). O mesmo Peter Drucker, em "A nova sociedade, anatomia da sociedade industrial", de 1950, afirmando a inexistência de um proletariado nos EUA, sustentava a necessidade de, numa sociedade industrial, considerar-se o trabalho como "uma fonte de capital" e não como uma mercadoria (1957, cap. 25). Em A revolução educativa, 1959, afirmava que, na nova organização social, o trabalhador manual tendia a se tornar improdutivo e o trabalho verdadeiramente produtivo passava a ser o trabalho baseado na mente. Nesse sentido, a gente instruída era o "capital" de uma sociedade desenvolvida (1974, p. 219).

A teoria do capital humano brota num ambiente extremamente fértil, onde a velocidade de crescimento impõe a cada momento de evolução uma perspectiva diferente aos cientistas sociais envolvidos na análise da sua dinâmica. As soluções surgem muitas vezes mais com o sentido de contornar questões políticas do que como uma revisão dos procedimentos técnicos e econômicos. A teoria do capital humano é um produto típico do 
desenvolvimento econômico americano. É produto do capitalismo mais desenvolvido e elemento decisivo da atualização e consolidação do conceito de capitalismo sem proprietários, ou sem classes sociais contrastantes.

Em plena Guerra Fria, a teoria do capital humano veio preencher um lugar já bem determinado dentro do pensamento social americano. E (casualmente?) trouxe um lenitivo para o dilema que ameaçava dilacerar a alma liberal americana desde os tempos de Taylor. Esse lenitivo está definido com bastante clareza numa frase de Theodore Schultz: "Os trabalhadores tornaram-se capitalistas não em consequência da propriedade de ações das corporações, como o folklore o considerou, mas em virtude da aquisição de conhecimentos e capacidades que possuíam valor econômico" (1961, p. 3).

Essa afirmativa de Schultz parece resumir todo o conteúdo e a razão de ser da teoria. Na verdade, ela tem um significado muito especial nos escritos de Schultz, chegando a ser reproduzida em, pelo menos, outros dois de seus textos, em 1963 e em 1971. Mas, o sentido mais profundo da teoria não se resolve nessa interpretação da "revolução" vivida pela sociedade americana e que tanto agitava a tradição liberal do país (Berle Jr. op.cit., p. 25s). O conflito ideológico-político contido na disjuntiva jurídica "poder sem propriedade-propriedade sem poder" era substituído por uma fórmula científica que contava com a indiscutível qualificação científica da mensuração. É nesse ponto que a teoria do capital humano encaixa nas preocupações dos setores dirigentes da sociedade americana a respeito da necessidade de articulação do sistema educacional com a esfera produtiva, manifestada desde a segunda metade do século 19.

Não deixa de chamar a atenção o fato de Schultz tratar a teoria da separação entre propriedade e controle desenvolvida por Berle e Means, que servira de inspiração e suporte a incursões no plano da reorganização da política estatal, e de fundamentar projeções teóricas na economia e na sociologia americanas, como pertencente ao folklore. O termo folklore parece ter um sentido bastante preciso, dentro dos objetivos de Schultz para a caracterização do conceito de capital humano. 
Seu uso encontra explicação na articulação do debate sobre a natureza das transformações da vida econômica por meio da expansão das sociedades anônimas, com questões arraigadas às tradições mais caras do país. Conforme Schultz, a resistência em entender a idéia de investimento em seres humanos estava no sentimento de repulsa do povo americano em admitir a possibilidade de cogitar de algo que lembrava a experiência do regime escravista:

Nossos valores e crenças nos inibem a considerar seres humanos como bens de capital, exceto na escravidão, e isso nós abominamos. (...) Não somos insensíveis à longa luta para livrar a sociedade do 'indentured service' e desenvolver instituições políticas e legais para manter o homem livre da servidão. (...) Tratar seres humanos como riqueza (...) parece reduzi-los outra vez a meros componentes materiais, a alguma coisa parecida com propriedade (1961, p. 2). ${ }^{6}$

A expressão "indentured service" remete a uma questão crucial que estava envolvida na discussão da propriedade corporativa e das expressões que essa discussão adquiria a partir das análises de Berle e Means. Schultz, propositadamente ou não, projetava uma sombra de suspeita sobre o sistema de propriedade acionária, vinculando-a a práticas ultrapassadas, dignas de uma economia escravocrata, que tratava o trabalhador escravo como capital fixo, elemento primário da propriedade escravista, fazendo secundária a sua expressão territorial cujo valor só podia ser estimado com a vinculação do trabalhador a ela.

A idéia de indentured service aparece em outro momento do texto de Schultz para indicar as distorções que o sistema de treinamento em serviço tendia a apresentar, comprometendo a boa regra do "negócio". Faz co-

6 A expressão indentured service é usada com referência ao regime escravista e aí ela tem um sentido diferente da de "contrato de aprendizagem", como em geral é traduzida nos textos de Schultz aqui mencionados. Refere-se a "serviço por dívida" ou "escravidão por dívida", sistema que foi muito usado nas colônias inglesas e que, inclusive, teve uma versão brasileira, na região dos plantios de exportação, através da fórmula da "obrigação por dívidas" (Ver a respeito: Eric Williams, 1975, cap 1; ver SAUL, 1990b, cap 4; entre outros). 
mentários, então, sobre o montante de dinheiro aplicado anualmente (cerca de 15 bilhões de dólares anuas em fins dos anos 50) no "treinamento no emprego", que "passava a cheirar legalmente a indentured service", em virtude da dificuldade de implementar acordos de aprendizagem no serviço. Não obstante a ambigüidade que o texto possa sugerir com a expressão "indentured service" (na tradução para a língua portuguesa, a expressão é traduzida como "contrato de serviço"), o que se infere dessa avaliação de Schultz é que as empresas tendiam a transferir os custos da aprendizagem de seus empregados para pagamento em trabalho.

De outra parte, quem devia suportar os gastos de 15 bilhões de dólares anuais aplicados no treinamento no emprego? Utilizando estudo de Gary Becker a respeito de treinamento no emprego e servindo-se de seus argumentos, Schultz observava que nos mercados competitivos, os empregados deviam cobrir todos os custos e que nenhum desses custos deveria ser suportado pelas empresas. E isso porque essa aprendizagem implicava criar capacidades técnicas gerais, as quais podiam ser perfeitamente transferidas para os cursos escolares regulares.

No terreno da educação formal, as coisas pareciam mais tranqüilas para Schultz, uma vez que o investimento subia a taxas rápidas e que isso podia representar uma elevação da renda das pessoas. Seguem-se avaliações dos custos totais com a educação, da relação entre esses custos com a renda do consumidor e as suas alternativas, da elevação do patrimônio da educação na força de trabalho e dos efeitos do aumento do patrimônio educacional na renda nacional.

Dado destacável nessas avaliações é o valor destinado pelos estudantes à educação. Embora de difícil mensuração, Schultz avaliava que, por volta de 1900, o total desse valor era aproximadamente de um quarto dos custos totais em educação elementar, secundária e superior. Em 1956, representavam mais de dois quintos dos custos totais. Em termos monetários, os valores seriam os de 400 milhões de dólares, em 1900, e 28 bilhões e 
700 milhões, em 1956. Aí também estava implicado o aumento dos custos reais da educação, que teriam sido de três ou quatro vezes maior do que a renda do consumidor e crescido cerca de três vezes e meia a formação bruta do capital físico em dólares. Tudo, evidentemente, em decorrência da lei do mercado, da oferta e da procura da educação. Se tratássemos a educação como puro investimento, observava Schultz, os resultados iriam sugerir que os rendimentos destinados à educação seriam um investimento bastante mais atraente do que os relativos ao capital não-humano (ibid., p. 11). Tão simples assim.

Da análise de Schultz e das sugestões de políticas que oferece no final do texto de 1961, pode-se delinear a perspectiva em que se direciona a teoria do capital humano e de seu papel na legitimação das práticas empresariais da organização do trabalho e na preservação do dinamismo econômico dos EUA.

Em primeiro lugar, a fórmula anunciada por Schultz, segundo a qual os trabalhadores se haviam tornado capitalistas por serem portadores de conhecimentos de valor econômico, ou seja, trabalhadores e empresários eram igualmente capitalistas, ademais de ser uma solução realmente imaginativa para recuperar a dignidade liberal e o orgulho dos efeitos virtuosos da concorrência entre capitais, tinha também a vantagem de dar um basta definitivo na tendência de confundir-se a propriedade corporativa ora com uma forma de socialismo autóctone, ora como expressão representativa da experiência fascista. De outra parte, sob essa retórica dava-se legitimidade ao conhecido teorema das externalidades da economia, tal como a entendem alguns economistas, isto é, a externalização dos custos privados através da sua transformação em custos globais da sociedade. Processo este que pertence à dinâmica do sistema capitalista desde a sua origem e que se acelerava, na sociedade americana, desde o término da Guerra de Secessão, em 1865.

É necessário, nesse ponto, considerar a contribuição de François Vatin (1999) à elucidação desse processo. 
François Vatin, propondo-se a examinar o papel que a "formação" representa na sociedade contemporânea e suas relações com os graves problemas de desemprego, exclusão, dificuldades de inserção social, etc., levanta a hipótese segundo a qual o debate em torno do processo educacional se dá dentro da crise econômica e social, e que os seus resultados, atuando sobre a organização do trabalho, dão nova direção à questão social. Neste sentido, ele examina o modo como a noção de formação se insere na teoria econômica neoclássica moderna e projeta um contexto doutrinário propiciatório do desenvolvimento do culto que liga todas as dimensões sociais do conhecimento e do processo de aquisição desse conhecimento. De acordo com esta orientação, a formação passa a ser avaliada não por suas virtudes, mas por se transformar no dado decisivo do emprego. Daí resulta a dominância no debate, tanto nas empresas quanto nos governos, do problema da necessidade de adequação formação/emprego (1999, p. 170).

Na avaliação de Vatin, a teoria neoclássica coloca o mercado de trabaIho como lugar de um enfrentamento entre a oferta de trabalho (que emana dos indivíduos) e a demanda de trabalho (que deriva das empresas). As características da oferta e da demanda são dadas por antecipação a esse enfrentamento. Tomando-se em conta como variável que importa, no caso, a correspondente à profissão, o mercado de trabalho se apresenta como um vetor de competências adquiridas e de competências requisitadas. A problemática da adequação formação/emprego emerge quando se passa do quadro lógico da economia pura para o quadro de uma economia aplicada ou da economia social (Walras). Um desvio é introduzido nessa lógica que define o encontro no mercado de trabalho. Então,

aparece como evidente que são os ofertadores (os trabalhadores) que devem se adaptar às condições da demanda de trabalho que emana das empresas, ou, dito de outra maneira, é preciso aproximar o vetor das competências adquiridas pelos indivíduos às competências desejadas pelas empresas. (...) O objetivo requerido ao 
sistema de formação, tanto inicial quanto continuado, público ou privado, será, de acordo com essa visão, de produzir em quantidade e em qualidade as novas competências exigidas pelo sistema produtivo.

Dessa maneira, o que fica evidente ao senso comum é ser a formação o elemento que deve adaptar-se ao emprego e não o contrário, hipótese que assume caráter paradoxal. O caráter dialético real contido nos espaços sociais da formação e do emprego se perde em benefício da harmonia do postulado de senso comum com a economia neoclássica do mercado. A noção de capital humano, derivada da necessidade de realizar a adaptação da mercadoria trabalho aos imperativos do cliente-empresa, vem para interpretar esse paradoxo e dar-lhe um nome (op. cit., p. 171).

Entre as questões relevantes apontadas por Vatin, uma delas assume uma dimensão especial para entender o sentido que o conceito de capital humano representa no contexto da sociedade americana, em fins dos anos 50. De acordo com Vatin, a qualificação do trabalhador incorpora ao trabaIho a qualidade de serviço desse capital individual, a remuneração corresponderá ao montante acumulado desse capital. "Além de tornar legitima a hierarquia salarial com base na qualificação e nos títulos escolares", observa Vatin, "essa teoria permite assimilar plenamente trabalho e capital como mercadorias-fatores de produção" (ibid., p. 172).

Pode-se encontrar respaldo a essas observações, em qualquer leitura que se faça de textos de teóricos modernos do capital humano, trate-se de Mincer, Schultz ou Becker. Tais proposições básicas da teoria podem ser facilmente localizadas. Na proposta da teoria do capital humano, o trabalho pensado como fator de produção, juntamente com o capital físico, na formulação de Schultz, pretende ser uma inovação não apenas em termos de análise econômica como também pretende descortinar uma nova dimensão política para as disputas entre empresariado e sindicatos. Nesta direção, parece bastante sugestiva a forma como Schultz, no texto antes referido (1961, p. 8), busca, dentro do jargão da economia, demonstrar que os 
gastos aplicados na formação das capacidades individuais incrementam o "valor-produtividade do esforço humano (trabalho)" e resultam numa taxa positiva de retorno. Para estimar a magnitude do investimento humano, basta usar os mesmos procedimentos utilizados para avaliar o investimento em capital físico. A questão adicional que envolve o investimento humano é a dificuldade para caracterizar o que é investimento e o que é consumo. De acordo com Schultz, podem-se imaginar três tipos de gastos: os que privilegiam o consumo e que não acrescentam nada em termos de capacidades, que podem ser considerados puro consumo; gastos que privilegiam o desenvolvimento das capacidades individuais que são puro investimento; e gastos que buscam ambos efeitos. Nessa terceira categoria de gastos está a expressão mais importante do investimento humano e o que torna mais difícil a sua avaliação, em comparação com a possibilidade de avaliação de investimentos em capital físico. A solução para este problema é um método alternativo para estimar o investimento humano: tomar em consideração o seu produto e não o seu custo. Assim,

quando qualquer capacidade produzida pelo investimento humano torna-se parte do agente humano e não pode mais ser vendido. Entretanto, ele está 'em contato como o mercado', influenciando rendas e salários que o agente humano pode obter. O aumento em ganhos é o produto do investimento(Schultz, 1961, p. 8) (grifo RPS).

Aqui nos reencontramos com a reflexão de Vatin, a respeito da qualificação do serviço do trabalhador individual que se encontra, no mercado, em igualdade de condições com o capital do empresário (o assim chamado capital físico), como dois "fatores-mercadoria da produção". A idéia de serviço é fundamental para apreender o que se esconde sob a simplificação feita por Schultz ao indicar a maneira como se realiza o investimento em seres humanos. Se, num primeiro momento, a sua alusão ao caráter folclórico da forma de perceber o mundo do trabalho possa sugerir um avanço 
em relação às pretensões do movimento sindical, logo essa impressão se desfaz. O suposto equilíbrio de forças por ele identificado, que, no fundo, é o objetivo das organizações sindicais, contém, na verdade, uma nova fórmula de violar a lógica da ação sindical.

Um primeiro aspecto a examinar, nesse sentido, diz respeito ao objetivo principal do texto, a necessidade de a economia ter uma "visão mais ampla do capital", quer dizer, pensar o capital não apenas como capital físico, mas entender o incremento das habilidades do trabalhador como capital. Schultz está escrevendo no momento em que a revolução cibernética tende a se estender para toda a atividade econômica, nos EUA e em outros países industrializados. Este fato produz, como em qualquer mudança tecnológica importante, uma reavaliação geral das atividades produtivas, especialmente quanto à produtividade do trabalho nos diferentes ramos de atividades econômicas.

Quando se acompanha a análise de Ernest Mandel (1979, ver cap. VII e VIII) sobre os efeitos da terceira revolução tecnológica, verifica-se que a teoria do capital humano aparece como um novo ramo da economia, resultante da pressão crescente que se faz sentir sobre a composição orgânica do capital, a partir do aumento da competição internacional e da aceleração das invenções e inovações tecnológicas, após a Segunda Guerra Mundial. O estímulo à intensificação do processo de trabalho, à aceleração da divisão do trabalho, da sua racionalização e especialização, colocou em cena a necessidade de se definir efetivamente a "rentabilidade material" dos gastos feitos na educação e a se mencionar às claras o imperativo das "inversões produtivas" no sistema educacional.

Ou seja, a teoria do capital humano vem a reboque de uma transformação substantiva no movimento do capital, que tem sua dinâmica alterada, de acordo com Mandel, em razão da modificação do seu tempo de rotação na economia. Assim, por exemplo, o tempo de rotação do capital fixo tende a diminuir em virtude do aumento de velocidade da obsolescência das má- 
quinas, o que implica a necessidade de uma reprogramação de custos. Essa reprogramação tem de ser efetivada com grande precisão e obriga a operar com rigor o registro de informações em toda a economia, incluindo-se aí a previsão e planificação dos custos salariais a longo e médio prazos. Isto é, a alteração do tempo de rotação do capital fixo repercute no conjunto da economia, impondo a necessidade de se reavaliar o tempo de rotação do capital circulante. Por outra parte, esses acontecimentos revelam que a delegação de poder que se supunha ocorrer nas corporações com a separação entre controle e propriedade, se apresente, na verdade, como uma delegação de poder sobre detalhes da atividade produtiva, que tem correspondência em uma crescente concentração de poder sobre as decisões verdadeiramente estratégicas a respeito da expansão da empresa. É a própria forma de organização do capital que se altera, transferindo-se da esfera da produção, passando para a esfera da acumulação para chegar à esfera da reprodução (1979, p. 242).

Um dos motivos para Schultz caracterizar como folclóricas idéias como as de Berle e Means e a teoria da administração científica que Ihe está subjacente, é a sua ineficiência diante dos novos imperativos propostos à economia, e a resistência por parte dos sindicatos com referência à sua implementação. A noção de capital humano parece servir sob medida para atualizar soluções que estavam embutidas na racionalização da atividade produtiva, desde os tempos de Taylor, de modo a reverter a resistência sindical através do incentivo à competição entre os trabalhadores e à individualização dos salários. A identificação da qualidade do serviço, do seu capital individual, colocaria o trabalhador em pé de igualdade com o capital senso estrito, no mercado.

Deste ponto pode-se visualizar uma outra maneira em que Schultz deixa perceber a sutileza política da teoria que patrocina, intencionalmente ou não. O investimento humano, como habilidade que passa a ser parte do individuo, seu capital, não pode ser vendido, como ele declara. Na forma 
de "serviço" ou "atividade", porém, o investimento humano (como esforço humano, trabalho) pode ser alugado em troca de pagamento por tempo determinado. Duas questões estão envolvidas aqui. O trabalho parece experimentar uma transformação substantiva e, em conseqüência, parece alterar-se a natureza da relação jurídica entre capital e trabalho.

Segundo um especialista da área da ciência jurídica (Correas, 1980), o critério científico mais apropriado para diferenciar a natureza de um contrato de trabalho de qualquer outra forma de contrato reside na natureza do que é trocado. Se se trata de uma mercadoria qualquer, é um contrato civil. Se é força de trabalho como mercadoria, é contrato de trabalho. A diferença específica diz Correas, "consiste em que, em um caso (do contrato civil), o objeto é o resultado de um trabalho e, no caso do (contrato de) trabalho é o trabalho mesmo". No contrato de trabalho, a relação de trabalho se apresenta como dado característico de uma situação de subordinação do trabaIhador em relação ao patrão, expressando o enfrentamento entre classes diferentes no conjunto da sociedade (Correas, p. 122-131). Diversamente, na situação de compra e venda típica do contrato civil, supõe-se a a simetria entre os intervenientes na relação de troca.

Coloque-se a questão em outros termos. Schultz, embora não o admita abertamente, de certo modo interpreta o movimento de racionalização das empresas e dos efeitos da organização taylorista, que se difunde a todas as esferas econômicas, provocando um processo de homogeneização do trabalho fabril e de escritório (ver Braverman, parte IV). Ao tomar o trabalhador como capital de si mesmo e, por conseguinte, como um vendedor de serviços, e levando em conta que serviço representa o valor de uso particular do trabalho, na medida em que este não é útil como coisa, mas como atividade (Marx, 1974, p. 87; ver também Correas, páginas citadas), Schultz, como intérprete da nova teoria, propõe uma equação econômica da relação entre capital e trabalho cuja repercussão política irá marcar o futuro da economia e da sociologia americanas. De acordo com Vatin, a 
teoria do capital humano proporcionava a adaptação da mercadoria-trabaIho aos objetivos da empresa, ao mesmo tempo em que transformava a pessoa do trabalhador (op.cit., 171). Isso correspondeu a dar um novo e sofisticado toque teórico ao movimento instaurado com a difusão da gerência científica criada por Taylor, há mais de setenta anos atrás. Fundindo numa única categoria todo o trabalho assalariado, estivesse esse trabalho vinculado à industria ou não, processava-se a um só tempo, a homogeneização do trabalho e a individualização do trabalhador. A resultante atomização dos salários projetava o acirramento da competição entre os trabalhadores e aplicava um duro golpe nas lutas sindicais, interferindo diretamente nas pretensões de sustentação da negociação salarial coletiva. Aparentemente, o processo jogava os problemas salariais para a esfera do mercado de trabaIho. Na realidade, porém, ele favorecia as necessidades empresariais de aliviar os custos salariais, favorecendo a sua programação fora da escala de flutuações daquele mercado.

A idéia do homem como "bem de capital" (capital good) (Schultz, 1961, p. 2), nos projeta para frente, para a emergência da "sociedade dos serviços", da "civilização terciária", para a "sociedade do conhecimento", para a "sociedade pós-industrial", expressões que viriam a dominar as ciências sociais nas décadas seguintes. Mas ela também nos remete de volta ao passado ao lembrar a velha noção de propriedade no sentido amplo, que se desenvolveu enlaçada no conceito de direitos humanos e circulou nos primeiros momentos de vida da república americana, na doutrina dos federalistas (Pipes, 200, cap. XII), e que marcou toda trajetória da configuração institucional do país. 


\section{Referências:}

ALTVATER, Elmar. O preço da riqueza. Trad. Leo Wolfgang Maar. São Paulo: Ed.UNESP, 1995 [1992].

BARITZ, Loren. Los servidores del poder. Madrid: Ed. Europa, 1961.

BECKER, Gary. El capital humano. Madrid: Alianza Editorial, 1983[1964].

BELL, Daniel. The coming of post-industrial society. A venture in social forecasting. New York: Basic Books, Inc., Publishers, 1973.

BERLE Jr., Adolf A. \& MEANS, Gardiner C. A propriedade privada na economia moderna. Rio de Janeiro: Ed. Ipanema, 1957.

BERLE, Adolf Jr. \& MEANS, Gardiner. Corporation. In Enciclopaedia of Social Sciences. 6ed. New York: The MacMillan Company, 1967.

BERLE, Adolf Jr. \& MEANS, Gardiner. The modern corporation and private property. New York : Harcourt Brace, 1968

BERLE, Adolf Jr. Poder sin propiedad. Una nueva evolución en la economia política americana. Trad. Juan Carlos Pellegrini. Buenos Aires: Tipografica Editora Argentina, 1961 [1959].

BLACKBURN, Robin (org.) Ideologia na ciência social. Ensaios críticos sobre a teoria social. Trad. Aulyde Rodrigues. Rio de Janeiro: Paz e Terra, 1982, p.42-56.

BLAUG, Mark. La metodologia de la economia. Trad. Ana Martinez Pujana. Madrid: Alianza Editorial, 1985[1980].

BLAUG, Mark. La pensée économique. Origine et développment. Trad. Alain e Christiane Alcouffe. Paris: Economica, 1986.

BOURNE, Randolph. "Who wons the universities?" The World of Randolph Bourne. A anthology. New York: E. P. Dutton \& Co. Inc., p. 72-5. 1965.

BRAVERMAN, Harry. Trabalho e capital monopolista. A degradação do trabalho no século XX. 3a.ed. Trad. Nathanael C. Caixeiro. Rio de Janeiro: Zahar Editores, (1981)[1974]. 
BURREL, Gibson \& MORGAN, Gareth. Sociological Paradigms and Organizational Analysis. Elements of the Sociology of Corporate Life. Suffolk: Ipswich Book Company.

CARNOY, Martin (ED.). International Encyclopedia of Economics of Education. 2. Ed. Cambridge: Pergamon, 1995.

CORIAT, Benjamin. Ciência, técnica y capital. Trad. María Teresa Martínez e Miguel Pellicer. Madrid: Blume Ediciones, 1976.

CORIAT, Benjamin El taller y el cronómetro. Ensayo sobre el taylorismo, el fordismo, y la producción en masa. México: Siglo XXI, 1982 [1979].

CORIAT, Benjamin. La robótica. Trad.(¿) Madrid: Editorial Revolución, 1985 [1980].

CORIAT, Benjamin. El taller y el robot. Ensayos sobre el fordismo y la producción en masa en la era electrónica. 3a. ed. Trad. Rosa Ana Dominguez Cruz. Mexico: Siglo XXI, 1996 [1990].

CORREAS, Oscar. La ciencia jurídica. México: Universidad Autónoma de Sinaloa, 1980.

DAVIS, Kingsley \& MOORE, Wilbert. Alguns princípios de estratificação social. In VELHO, Otávio G. et alii (Organizadores). Estrutura de classes e estratificação social. 9a. ed. Rio de Janeiro: Zahar, p. 114-132. 1981 [1945].

DICKSON, David. Tecnologia alternativa. Trad. Fernando Valero. Madrid: $\mathrm{H}$. Blume Editores, 1980 [1978].

DRUCKER, Peter. Concept of the Corporation. New York: The John Day Company, 1946.

DRUCKER, Peter. A nova sociedade. Anatomia do sistema industrial. Trad. Esmerino Magalhães. Rio de Janeiro: Editora Ipanema, 1957 [1950].

DRUCKER, Peter. La revolución educativa. In ETZIONI, Amitai \& ETZIONI, Eva (Compiladores y presentadores). Los cambios sociales. Fuentes, tipos y consecuencias. Trad. Florentino M. Torner. México: Fondo de Cultura Económica, p. 216-221. 1973 [1968]. 
ETZIONI, Amitai \& ETZIONI, Eva (Compiladores y presentadores). Los cambios sociales. Fuentes, tipos y consecuencias. Trad. Florentino M. Torner. México: Fondo de Cultura Económica, 1973 [1968].

GIEDION, Siegfried. La mecanización toma el mando. Trad. Esteve Riambau i Sauri. Barcelona: Gustavo Gili, 1978[1948].

GOULDNER, Alvin. La crisis de la sociología ocidental. Trad. Nestor Míguez. Buenos Aires: Amorrortu, 1973.

GRAMSCl, Antonio. Cadernos do cárcere. Trad. Carlos Nelson Coutinho. Rio de Janeiro: Civilização Brasileira, 2000 [1932].

HILFERDING, Rudolf. El capital financiero. México: Instituto Cubano del Libro, 1973 [1910].

LUKACS, Georg. História e consciência de classe. Trad. Telma Costa. Porto: Escorpião, 1974 [1922].

MANACORDA, Paola. El ordenador del capital. Razón y mito de la informática. Trad. Miguel Pellicer. Madrid: H. Blume Ediciones, 1982 [1976].

MANDEL, Ernst. El capitalismo tardio. Trad. Manuel Aguilar Mora. México: Ediciones Era, 1979 [1972].

MARX, Karl. El capital. Libro 1- capítulo VI (inédito). Trad. Pedro Scaron. Buenos Aires: Siglo XXI, 1974 [1863-1866].

MINCER, Jacob. Investment in human capital and personal income distribution. The Journal of Political Economy, vol. LXVI, n. 4, p. 281-302, august. 1958

ERDRUM, Lars \& ERIKSON, Truls. Intellectual capital: a human capital perspective. Journal of Capital Intellectual. Bradford, Vol.2, n. 2, p. 127-41. 2001.

NICOLAUS, Martin. A organização profissional da sociologia: um enfoque a partir da base. In BLACKBURN, Robin (org.) Ideologia na ciência social. Ensaios críticos sobre a teoria social. Trad. Aulyde Rodrigues. Rio de Janeiro: Paz e Terra, 1982 [1971]. p. 42-56. 
NOBLE, David F. Technology and the commodification of higher education. Disponível em <http:/www.monthlyreview.org/0302noble.htm>, 2002.

OROZCO, José Luis (Prólogo, seleccion, traducción y notas). El testimonio político norteamericano (1890-1980). V. I. México: SEP/UNAM, 1982.

PARSONS, Talcott. An analytical approach to the theory of social stratification. The American Journal of Sociology, n. 45, p. 841-862, may. 1940.

PARSONS, Talcott \& SMELSER, Neil. Economy and Society. A Study of the Integration of Economic and Social Theory. New York: The Free Press, 1965.

PIPES, Richard. Property and freedom. New York: Alfred A. Knopf, 2000.

SAUL, Renato P. Corporativismo, as duas faces de Janus. Cadernos de Sociologia, n. 2, p. 51-98, maio. 1990a.

SAUL, Renato. A modernidade aldeã. Porto Alegre: Ed. UFRGS, 1990b

SHONFIELD, Andrew. Capitalismo moderno. Trad. Alvaro Cabral. Rio de Janeiro: Zahar Editores, 1968.

SCHULTZ, Theodore W. Investment in human capital. The American Economic Review, v. LI, n. 1, p. 1-17, march.1961.

SCHULTZ. Theodore W. Valor económico de la educación. Trad. Sonia Tancredi. México: Unión Tipográfica Editorial Hispano Americana, 1968 [1963].

SCHULTZ, Theodore W. O capital humano. Investimentos em educação e pesquisa. Trad. Marco Aurélio de Moura Matos. Rio de Janeiro: Zahar Editores, 1973 [1971].

SOHN-RETHEL, Alfred. Trabajo manual y trabajo intelectual. Crítica de la epistemologia. Barcelona: El Viejo Topo, 1980 [1975?].

SOHN-RETHEL, Alfred. Economia dual da transição. In Processo de trabalho e estratégias de classe (apres. ed. brasileira de Fabio Stefano Erber). Rio de Janeiro: Zahar Editores, 1982 [1976].

TAYLOR, Frederick W. Princípios de administração científica. Trad. Arlindo Viera Ramos. São Paulo: Atlas, 1963 [1911]. 
THOMPSON. Edward P. Tradición, revuelta y conciencia de clase. Estudios sobre la crisis de la sociedad preindustrial. Trad. Eva Rodriguez. Barcelona: Editorial Gritica, 1984 [1979].

VATIN, François. Le travail, sciences et societé. Bruxelles: Ed. de l'Université de Bruxelles, 1999.

WILLIAMS, Eric. Capitalismo e escravidão. Trad. e notas: Carlos Nayfeld. Rio de Janerio: Ed. Americana, 1975 [1944).

Recebido: 31/03/2004

Aceite final: 06/07/2004

\section{Resumo}

O artigo pretende reconstituir a trajetória da teoria do capital humano, no contexto da sua sociedade de origem, os Estados Unidos. A partir da identificação de tendências presentes no pensamento social americano, marcadamente do orientado, de início, para a organização do trabalho industrial através das experiências levadas a efeito por Frederick Taylor e, depois, pela teorização a respeito de um novo conceito de propriedade emergente no processo de organização das grandes empresas de capital acionário, enquadra-se a teoria do capital humano no campo de resolução do grande dilema do liberalismo americano, o da institucionalização de uma sociedade sem classes.

Palavras-chave: pensamento social, liberalismo, relações de propriedade, taylorismo, capital humano. 